\title{
Root proliferation in native perennial grasses of arid Patagonia, Argentina
}

\author{
Yanina A TORRES ${ }^{1}$, Carlos A BUSSO ${ }^{1 *}$, Oscar A MONTENEGRO ${ }^{2}$, Leticia ITHURRART ${ }^{1}$, \\ Hugo D GIORGETTI ${ }^{2}$, Gustavo RODRÍGUEZ ${ }^{2}$, Diego BENTIVEGNA ${ }^{1}$, Roberto E BREVEDAN ${ }^{1}$, \\ Osvaldo A FERNÁNDEZ ${ }^{1}$, María M MUJICA ${ }^{3}$, Sandra S BAIONI ${ }^{1}$, José ENTÍO ${ }^{3}$, \\ María N FIORETTI ${ }^{1}$, Guillermo TUCAT $^{1}$ \\ ${ }^{1}$ Agronomy Department, National University of the South and CERZOS (CONICET), Bahía Blanca 8000, Argentina; \\ ${ }^{2}$ Experimental Farm EEA INTA Patagones, Ministery of Agrarian Issues, Carmen de Patagones 8504, Argentina; \\ ${ }^{3}$ Faculty of Agrarian Sciences, National University of La Plata, La Plata 1900, Argentina
}

\begin{abstract}
Pappophorum vaginatum is the most abundant $\mathrm{C}_{4}$ perennial grass desirable to livestock in rangelands of northeastern Patagonia, Argentina. We hypothesized that (1) defoliation reduce net primary productivity, and root length density and weight in the native species, and (2) root net primary productivity, and root length density and weight, are greater in P. vaginatum than in the other, less desirable, native species (i.e., Aristida spegazzinii, A. subulata and Sporobolus cryptandrus). Plants of all species were either exposed or not to a severe defoliation twice a year during two growing seasons. Root proliferation was measured using the cylinder method. Cylindrical, iron structures, wrapped up using nylon mesh, were buried diagonally from the periphery to the center on individual plants. These structures, initially filled with soil without any organic residue, were dug up from the soil on 25 April 2008, after two successive defoliations in mid-spring 2007. During the second growing season (2008-2009), cylinders were destructively harvested on 4 April 2009, after one or two defoliations in midand/or late-spring, respectively. Roots grown into the cylinders were obtained after washing the soil manually. Defoliation during two successive years did reduce the study variables only after plants of all species were defoliated twice, which supported the first hypothesis. The greater root net primary productivity, root length density and weight in $P$. vaginatum than in the other native species, in support of the second hypothesis, could help to explain its greater abundance in rangelands of Argentina.
\end{abstract}

Keywords: Aristida species; competitive ability; Pappophorum vaginatum; Sporobolus cryptandrus; warm-season perennial grasses

Citation: Yanina A TORRES, Carlos A BUSSO, Oscar A MONTENEGRO, Leticia ITHURRART, Hugo D GIORGETTI, Gustavo RODRÍGUEZ, Diego BENTIVEGNA, Roberto E BREVEDAN, Osvaldo A FERNÁNDEZ, María M MUJICA, Sandra S BAIONI, José ENTÍO, María N FIORETTI, Guillermo TUCAT. 2014. Root proliferation in native perennial grasses of arid Patagonia, Argentina. Journal of Arid Land, 6(2): 195-204. doi: 10.1007/s40333-013-0201-z.

Root competition is the major competition form in arid and semiarid environments (Fowler, 1986). Space occupation in the soil, of primary importance in root competition, depends upon root length and biomass (Casper and Jackson, 1997). Physicochemical heterogeneity of soils is well known (Jackson and Caldwell, 1993). For example, water and nutrient availability, toxic ion concentration, water infiltration and other factors that might affect plant growth and survival can vary along short distances within the soil (Fitter, 1976). Root proliferation toward small soil volumes with favorable chemical and physical characteristics has been shown in several species (Eissenstat and Caldwell, 1989). These responses are mechanisms that al-

\footnotetext{
*Corresponding author: Carlos A BUSSO (E-mail: cebusso@criba.edu.ar)

From the seventh author onward, all authors contributed equally to this research work.

Received 2013-02-19; revised 2013-06-17; accepted 2013-08-04

(C) Xinjiang Institute of Ecology and Geography, Chinese Academy of Sciences, Science Press and Springer-Verlag Berlin Heidelberg 2014
} 
low plants to explore more efficiently the soil environment (St John et al., 1983).

Favorable soil microsites, free from roots, constitute important areas for root competition. Rapid root proliferation toward those soil areas may be a major aspect in contributing to determine the competitive ability or defoliation tolerance of a given species (Eissenstat and Caldwell, 1989; Caldwell et al., 1991a, b).

Some perennial grasses tolerant to defoliation can assign assimilated carbon preferentially to re-establish a photosynthetic canopy after defoliation at the expense of root growth (Briske and Richards, 1995). However, maintenance of root growth after defoliation has also been reported in species tolerant to defoliation (Hodgkinson et al., 1989). A continued soil resource exploration is a major determinant of regrowth after defoliation (Caldwell and Richards, 1986). Timing and frequency of defoliation may regulate carbon partitioning to roots in several species (Dunn and Frommelt, 1998).

Saint Pierre et al. (2002) reported a greater root proliferation on defoliated and undefoliated plants of the $\mathrm{C}_{3}$, cool-season, last-seral, competitive perennial grass Nasella clarazii (Ball) Barkworth than on those of the $\mathrm{C}_{3}$, cool-season, early-seral, less competitive perennial grass Amelichloa ambigua (Speg.) Arriaga \& Barkworth. Greater root invasion to disturbed soil, free from roots, was also reported for the more competitive Agropyron desertorum (Fisch. ex Link) J.A. Schultes than for the less competitive Pseudoroegneria spicata (Pursh) A. Löve (Eissenstat and Caldwell, 1989). Plasticity to rapidly modify root growth has been shown to be greater on more competitive species (Crick and Grime, 1987). A greater uptake area (e.g., through a higher root length density) contributes to a greater soil volume exploration and subsequent resource acquisition in several species (Caldwell and Richards, 1986).

Studies are available about aboveground plant response to grazing/defoliation in natural grassland ecosystems (Valentine, 1990). However, the belowground part is the hidden half of the whole story and often missing. Therefore, comprehensive root system studies are essential to get a complete picture of plant responses to stress.
Cover, density and frequency values for Pappophorum vaginatum Buckley have been shown to be greater than those for other native species in rangelands of northeastern, arid Patagonia, Argentina (e.g. Aristida spegazzinii Arechav., A. subulata Henrard and Sporobolus cryptandrus (Torr.) A. Gray; Giorgetti et al., 1998; 1999; 2000a). Sporobolus cryptandrus is also a widespread perennial grass in rangelands of Europe (Quinn and Ward, 1969), Canada (Kilcher and Looman, 1983), USA (Svejcar et al., 2008), and China (Shinoda et al., 2010). Those results suggest that $P$. vaginatum is likely to take a greater share of the soil resources compared with those other native species. A greater root growth (proliferation) toward unexplored soil areas could be a mechanism that allows $P$. vaginatum a greater abundance in the plant community. To address this question we studied the effects of an early and mid-season defoliation on various root proliferation parameters in the $\mathrm{C}_{4}$ native plant species $P$. vaginatum, A. spegazzinii, A. subulata and S. cryptandrus in rangelands of northeastern arid Patagonia, Argentina. Hypotheses of this study were that (1) defoliation reduces root proliferation in the native species, and (2) root proliferation is greater on $P$. vaginatum than on the other native study species.

\section{Materials and methods}

\subsection{Study site}

Studies were conducted during 2007, 2008 and early 2009 within an exclosure to domestic livestock in the Chacra Experimental de Patagones, Buenos Aires, Argentina (40'39'49.7"S, 62 $53^{\prime} 6.4^{\prime \prime} \mathrm{W} ; 40 \mathrm{~m}$ asl), within the Phytogeographical province of the Monte (Cabrera, 1976). Climate belongs to temperate semiarid, with higher precipitations during the summer and fall seasons (Giorgetti et al., 2000b). Several climatic parameters measured at the study site are shown in Fig. 1.

Soil is a typical Haplocalcid. Average $\mathrm{pH}$ is 7 , and the soil layer depth is not a constraint factor for root growth in the soil profile. The plant community is characterized by an open, shrubby stratum which includes different-quality, herbaceous species for cattle raising (Giorgetti et al., 1997). Dominance of a particular grass or shrubby species in the study region 

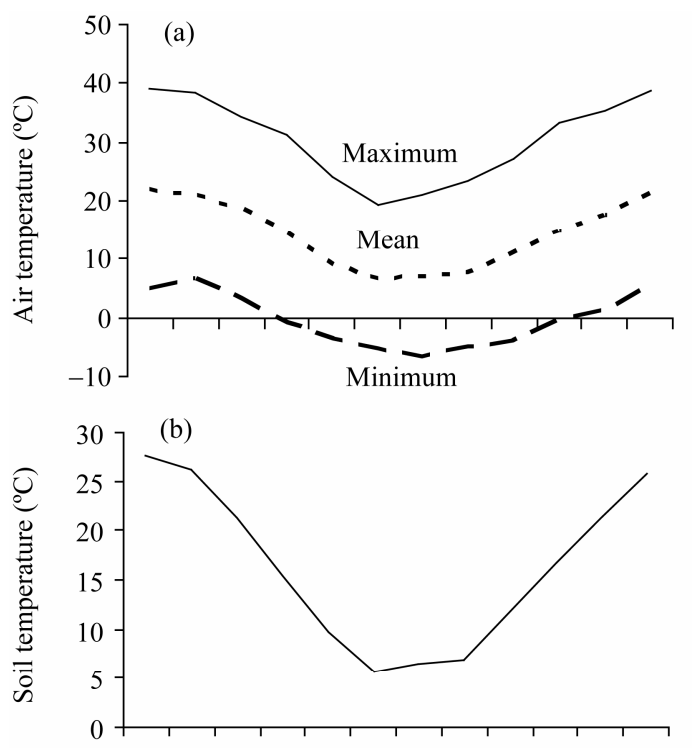

(c)
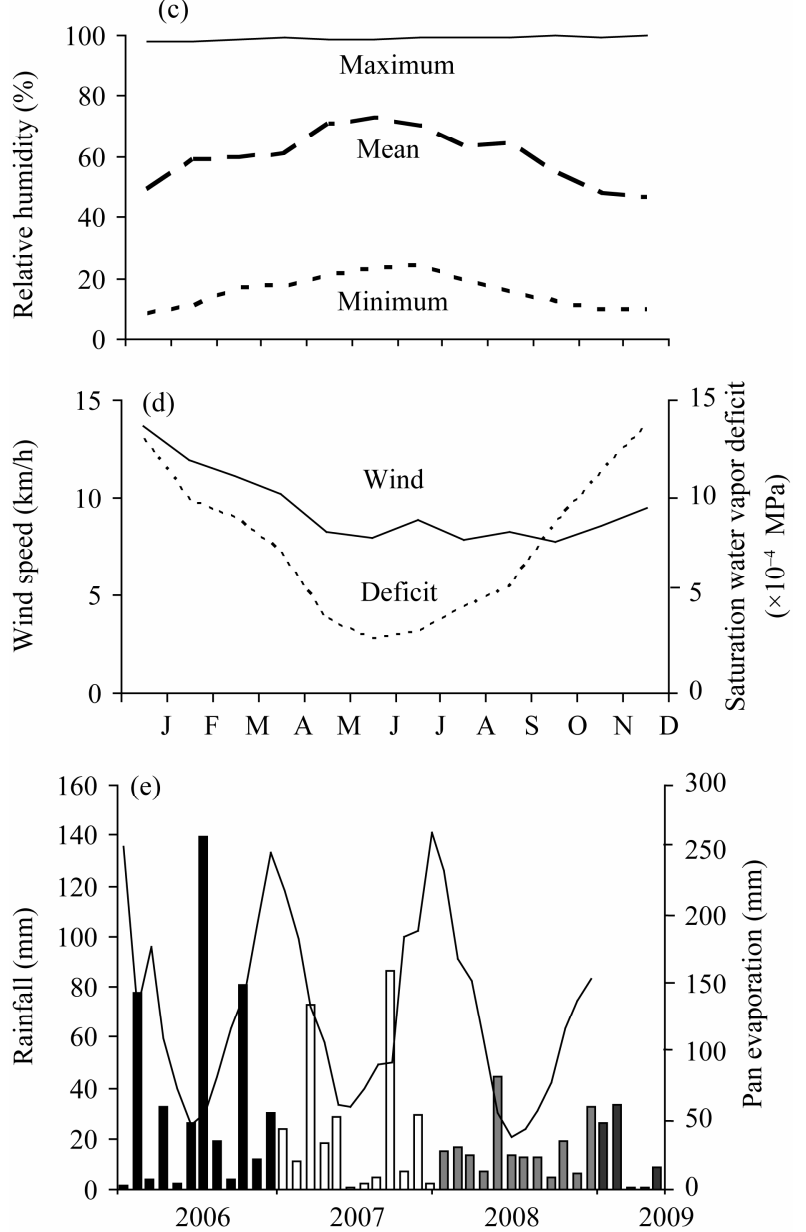

Fig. 1 Absolute monthly maximum and minimum, and mean monthly air temperatures (a); mean monthly soil temperatures at 0-20 cm soil depth (b); absolute monthly maximum and minimum, and mean monthly relative humidity (c); mean monthly wind speed and saturation water vapor deficit (d); and mean monthly pan evaporation and monthly rainfall during 2006, 2007 and 2008 at a meteorological station located at the study site (e). is partially dependent on grazing history and fire frequency and intensity (Distel and Bóo, 1996).

\subsection{Experimental design and defoliation treat- ments}

Plants of the native species $P$. vaginatum, A. spegazzinii, A. subulata and S. cryptandrus were within a 1-hm ${ }^{2}$ exclosure to domestic livestock. During August 2007 and September 2008, tiller number per plant was counted on each plant at the time of cylinder placement and at the time of their extraction as a measure of plant size. During the second growing period (September 2008), tiller number per plant was additionally counted at the time of cylinder replacement, when the second defoliation was imposed. Plant circumference was measured at the time that variable was evaluated. Since calculation of plant basal area was possible, tiller number was obtained on a per $\mathrm{cm}^{2}$ basis. The first defoliation (i.e., clipping) was made using scissors during winter (the plant dormancy period) across all plants to remove aftermath in 2007, before the start of the growing season. The purpose was that only aerial plant growth produced above 5 -cm stubble during the following warm growing season was used for sampling. This defoliation did not count as a treatment since plants were dormant at this time (i.e., aerial tissues were dead at this removal time, and then it was not the commencement of the defoliation managements). Defoliating plants while they are in a dormant stage, with minimal physiological function, does not influence future plant performance (Schacht et al., 1998). Thereafter, half of the plants of all species was defoliated twice within each of the study growing cycles (i.e., the defoliation treatment was repeated for all plants on both dates each growing cycle). During 2007-2008, defoliations were made on 5 and 11 November (mid-spring) 2007, and during 2008-2009, they were done on 19 November and 20 December 2008 (late-spring). At the time of the defoliation treatments, biomass was cut hanging leaves erect. Tillers of all four species were periodically dissected and observed under a stereoscopic binocular microscope (Nikon 55162, 10x) to determine both the developmental stage and height of the apical meristem. As a result, actively growing meristems (intercalary and leaf primordia in the growth apex) remained on 
the plants after the defoliation events. The height of the apical meristem from the stem basal area was $5.8 \pm 0.9 \mathrm{~mm}(n=15)$ in 2007, and $2.7 \pm 0.4 \mathrm{~mm}(n=15)$ in 2008 on undefoliated tillers of the native species at the time of defoliations. The other half of the plants remained undefoliated during the active growth period. However, these plants were defoliated in the winters of 2007 and 2008 (i.e, a period during the dormancy developmental morphology stage), and in falls of 2008 and 2009, respectively, so their biomass was the forage accumulated during each growing season. Defoliation treatments were delayed in the second growing cycle because of a lower rainfall during September to December in 2008-2009 (62 mm; i.e., a smaller plant growth) than in 2007-2008 (125.5 mm). This defoliation management mimics the short duration-high intensity, rotational grazing system applied at the "Monte" vegetation in the Chacra Experimental of Patagones (Giorgetti et al., 2006; mean $=0.13$ animal unit $/ \mathrm{hm}^{2}$ ). Within this system, some acceptable forage can be grazed twice by grazing livestock during their at least 30-day-stay in the paddocks (Giorgetti, 1995). In Argentina, an animal unit is defined as the annual average dry forage requirement of a $400-\mathrm{kg}$ cow that goes through gestation and subsequent nursing of a calf, until the $160-\mathrm{kg}$, 6-month-old calf is weaned, including the forage consumed by the calf (Giorgetti et al., 2006). Defoliations were applied to the same plants in each year, but different plants were used in different years. In all cases, plants were defoliated leaving $5 \mathrm{~cm}$ stubble height.

\subsection{Measurements}

During the spring of 2007,48 cylindrical, iron structures $(2$ treatments/species $\times 4$ species $\times 6$ replicates/treatment; hereafter called "cylinders") of $8 \mathrm{~cm}$ diameter and 40-cm length, were wrapped up using nylon mesh $(1 \mathrm{~cm} \times 1 \mathrm{~cm}$ opening; Saint Pierre et al. (2002); one end of the cylinder was left open; from now on called "bags"). Much care was taken to prevent roots from being pulled out or lost during excavation. After extracting soil cores using a pneumatic auger, cylinders were buried diagonally, from the periphery toward the center of each plant, at an angle of $15^{\circ}$ with respect to the vertical (Saint Pierre et al., 2002). Afterwards, each "bag" was filled with soil coming from the study site. This soil was previously screened $(0.355 \mathrm{~mm}$ mesh $)$ and then cleaned from roots and other residues. We assumed that roots growing into the cylinders came from the same plant they have above since surrounding plants were at least $30 \mathrm{~cm}$ away from the target plant (Saint Pierre et al., 2002). During the first study year, cylinders were placed on 5 November 2007, and dug up from the soil on 25 April 2008 (Table 1). This allowed us to determine the cumulative effects of two successive defoliations during mid-spring on root growth. During the following growth cycle (2008), there were not enough plants of $S$. cryptandrus to make the study, and therefore this species was not considered anymore. New plants were used this year, and a first set of 36 cylinders was buried in the soil on 19 November as described above (Table 1). These cylinders were dug up, and replaced by a second set of 36 cylinders on the same plants on 20 December of that year, at the same time of the second defoliation treatment in 2008 (Table 1). The first set of cylinders was extracted from the soil so easily that the second cylinder set was buried in the same places where there were the first cylinder set. This first set of cylinders allowed determining the effects of once defoliation on root growth

Table 1 Description of root growth measurement periods, and dates of the defoliation treatments and placement or extraction/replacement of the cylinders during 2007-2008 and 2008-2009 in all study species. At each placement date, six cylinders (replicates) were buried per species and defoliation treatment

\begin{tabular}{cccc}
\hline $\begin{array}{c}\text { Period of root growth } \\
\text { measurement }\end{array}$ & Date of defoliation treatment & Placement date of cylinders & Extraction/Replacement date of cylinders \\
\hline 26 Nov 2007 to 25 Apr 2008 & $\begin{array}{l}1^{\text {st }} \text { def. on 5 Nov } \\
2^{\text {nd }} \text { def. on 11 Nov }\end{array}$ & 26 Nov 2007 & 25 Apr 2008 \\
19 Nov 2008 to 20 Dec 2008 & $\begin{array}{l}1^{\text {st }} \text { def. on 19 Nov } \\
2^{\text {nd }} \text { def. on 20 Dec }\end{array}$ & 19 Nov 2008 2008 \\
20 Dec 2008 to 4 Apr 2009 & & 20 Dec 2008 & 4 Apr 2009 \\
\hline
\end{tabular}


from November to December in 2008. The second cylinder set was used to obtain the cumulative effects of two defoliations during mid- and late-spring on the root growth produced from December 2008 to 4 April 2009. Cylinders were destructively harvested; roots that protruded from them were carefully cut using scissors as to not make any disturbance of the soil plus roots contained in any cylinder. Soil plus roots within each cylinder were placed into polyethylene bags that were transported to the laboratory. Roots were separated from soil through manual sample washing using 60 mesh-screens (Williams and Baker, 1957). Root length was determined on images using the software ROOTEDGE 2.3b (Kaspar and Ewing, 1997). Images were determined after scanning roots that were included within two glass plates. The number of glass plates used per plant depended upon the amount of roots that grew into each individual cylinder: the greater it was this amount, the greater the number of glass plates needed for scanning. Since volume of the cylinders was known $\left(2,010.26 \mathrm{~cm}^{3}\right)$, root length density was calculated. Afterwards, roots were dried at $105^{\circ} \mathrm{C}$ for $72 \mathrm{~h}$ to obtain dry root weight. Finally, these samples were placed into a furnace to $550^{\circ} \mathrm{C}$ for $8 \mathrm{~h}$. Ash-free, root organic matter dry weight was obtained from the difference in the dry weights at $105^{\circ} \mathrm{C}$ and $550^{\circ} \mathrm{C}$ (AOAC, 1965). Root length and weight data were used to calculate root length/unit dry weight for each replicate sample. Root net primary productivity was calculated as $B_{t+1}-B_{t} / \Delta t$, where $B_{t+1}$ was the root biomass grown into the cylinders during $\Delta t$; $B_{t}$ was the root biomass within the cylinders at cylinder placement into the soil (i.e., equal zero), and $\Delta \mathrm{t}$ was the time interval between any placement and withdrawal of the cylinders.

\subsection{Statistical analysis}

Data were analyzed using the statistical software INFOSTAT (Di Rienzo et al., 2009). Data were transformed to $\ln (\mathrm{x}+1)$ (root length and weight per unit dry weight) and to $\sqrt{x}_{\mathrm{x}}$ (root length density) to comply with the normality and homocedasticity of variance assumptions (Sokal and Rohlf, 1987). Untransformed values are presented in tables. Root variables were analyzed using two-way ANOVA during the first study year (a unique sampling date) and using repeated measures ANOVA in the second study year, where factors were the species, the defoliation treatments, and the two sampling dates. The multivariate approximation was utilized using the Wilks' statistics (Wilks, 1932). When the interaction between any factor and time was not significant $(P>0.05)$, data from all dates were averaged. When the interaction was significant $(P<0.05)$ each sampling date was analyzed separately. Mean separation was conducted using the protected LSD of Fisher, with a significance level of 0.05 .

\section{Results}

\subsection{Tiller number per $\mathrm{cm}^{2}$ basal area}

The interaction between species and treatment was not significant $(P>0.05)$ at cylinder placement in August 2007 (Table 2). At this time, plants of $A$. spegazzinii and $A$. subulata showed an inherently greater $(P<0.05)$ tiller number $/ \mathrm{cm}^{2}$ than those of $P$. vaginatum and $S$. cryptandrus (Table 2). At this time, tiller number $/ \mathrm{cm}^{2}$ was similar $(P>0.05)$ between defoliated versus undefoliated plants in all study species. At the end of the study in August 2007, P. vaginatum showed the lowest $(P<0.05)$ tiller number $/ \mathrm{cm}^{2}$ when plants of all study species remained undefoliated (Table 2). At the same time, the greatest $(P<0.05)$ tiller number $/ \mathrm{cm}^{2}$ on defoliated plants of all species was shown in A. spegazzinii (Table 2). In addition, tiller number $/ \mathrm{cm}^{2}$ was similar $(P>0.05)$ between defoliated and undefoliated plants in all species but $A$. spegazzinii, which showed a greater $(P<0.05)$ tiller number $/ \mathrm{cm}^{2}$ on defoliated than on undefoliated plants (Table 2). At any time during September 2008, tiller number $/ \mathrm{cm}^{2}$ was again greater $(P<0.05)$ in both Aristida species than in $P$. vaginatum, and there were no differences in tiller number $/ \mathrm{cm}^{2}$ between defoliated versus undefoliated plants on any species (Table 2).

\subsection{Root net primary productivity}

During September 2008, the interaction with time was not significant $(P>0.05)$. This is why we averaged the values for the two sampling dates in that growing season. During both study periods, there were no significant differences $(P>0.05)$ between defoliation 
treatments (Fig. 2). Defoliated and undefoliated plants of $P$. vaginatum showed a greater $(P<0.05)$ root net primary productivity than $A$. spegazzinii and $S$. cryptandrus in August 2007 (Fig. 2). During September 2008, however, defoliated and undefoliated plants of $P$. vaginatum and $A$. spegazzinii showed a similar
$(P>0.05)$ root net primary productivity, although it was greater $(P<0.05)$ in $P$. vaginatum than in $A$. subulata (Fig. 2). Root net primary productivity values for all study species and defoliation treatments appeared to be greater during September 2008 than during $\mathrm{Au}-$ gust 2007 (Fig. 2).

Table 2 Tiller number per $\mathrm{cm}^{2}$ at the time of placement of the cylinders (26 November in 2007; 19 November in 2008) and at the end of the study (25 April in 2008; 4 May in 2009) on defoliated and undefoliated (control) plants of the study species

\begin{tabular}{|c|c|c|c|c|c|}
\hline & & \multicolumn{2}{|c|}{$2007-2008$} & \multicolumn{2}{|c|}{ 2008-2009 } \\
\hline & & Cylinder placement ${ }^{\mathrm{A}}$ & End of the study ${ }^{\mathrm{B}}$ & Cylinder placement ${ }^{\mathrm{A}}$ & End of the study ${ }^{\mathrm{B}}$ \\
\hline \multirow{2}{*}{$\begin{array}{c}\text { Pappophorum } \\
\text { vaginatum }\end{array}$} & Control & $0.85 \pm 0.10^{\mathrm{a}, \mathrm{a}}$ & $0.84 \pm 0.09^{\mathrm{a}, \mathrm{a}}$ & $0.99 \pm 0.20^{\mathrm{a}, \mathrm{a}}$ & $0.60 \pm 0.15^{\mathrm{a}, \mathrm{a}}$ \\
\hline & Defoliated & $0.57 \pm 0.09^{\mathrm{a}, \mathrm{a}}$ & $0.84 \pm 0.10^{\mathrm{a}, \mathrm{a}}$ & $1.17 \pm 0.45^{\mathrm{a}, \mathrm{a}}$ & $0.57 \pm 0.13^{\mathrm{a}, \mathrm{a}}$ \\
\hline \multirow{2}{*}{$\begin{array}{c}\text { Aristida } \\
\text { spegazzinii }\end{array}$} & Control & $2.70 \pm 0.53^{\mathrm{c}, \mathrm{a}}$ & $2.29 \pm 0.36^{\mathrm{b}, \mathrm{a}}$ & $2.87 \pm 0.47^{\mathrm{b}, \mathrm{a}}$ & $1.97 \pm 0.34^{\mathrm{b}, \mathrm{a}}$ \\
\hline & Defoliated & $3.36 \pm 0.53^{\mathrm{c}, \mathrm{a}}$ & $5.34 \pm 1.29^{\mathrm{b}, \mathrm{b}}$ & $2.20 \pm 0.17^{\mathrm{b}, \mathrm{a}}$ & $1.86 \pm 0.14^{\mathrm{b}, \mathrm{a}}$ \\
\hline \multirow{2}{*}{$\begin{array}{l}\text { Aristida } \\
\text { subulata }\end{array}$} & Control & $1.79 \pm 0.35^{\mathrm{b}, \mathrm{a}}$ & $1.93 \pm 0.32^{\mathrm{b}, \mathrm{a}}$ & $2.08 \pm 0.45^{\mathrm{b}, \mathrm{a}}$ & $1.35 \pm 0.36^{\mathrm{b}, \mathrm{a}}$ \\
\hline & Defoliated & $1.62 \pm 0.31^{\mathrm{b}, \mathrm{a}}$ & $2.12 \pm 0.46^{\mathrm{a}, \mathrm{a}}$ & $2.08 \pm 0.36^{\mathrm{b}, \mathrm{a}}$ & $2.11 \pm 0.34^{\mathrm{b}, \mathrm{a}}$ \\
\hline \multirow{2}{*}{$\begin{array}{l}\text { Sporobolus } \\
\text { cryptandrus }\end{array}$} & Control & $0.98 \pm 0.23^{\mathrm{a}, \mathrm{a}}$ & $2.46 \pm 0.50^{\mathrm{b}, \mathrm{a}}$ & n.d & n.d. \\
\hline & Defoliated & $0.76 \pm 0.20^{\mathrm{a}, \mathrm{a}}$ & $1.23 \pm 0.26^{\mathrm{a}, \mathrm{a}}$ & n.d. & n.d. \\
\hline
\end{tabular}

Note: each value is the mean \pm standard error of $n=6 .{ }^{A}$, the interaction between species and treatment was not significant $(P>0.05)$. Different letters before the comma indicate significant $(P<0.05)$ differences among species, and those after the comma significant $(P<0.05)$ differences between treatments. ${ }^{\mathrm{B}}$, there was a significant $(P<0.05)$ interaction between species and treatments. Different letters before the comma indicate significant $(P<0.05)$ differences among species within each treatment, and those after the comma indicate significant $(P<0.05)$ differences between treatments within each species. n.d.: not determined.

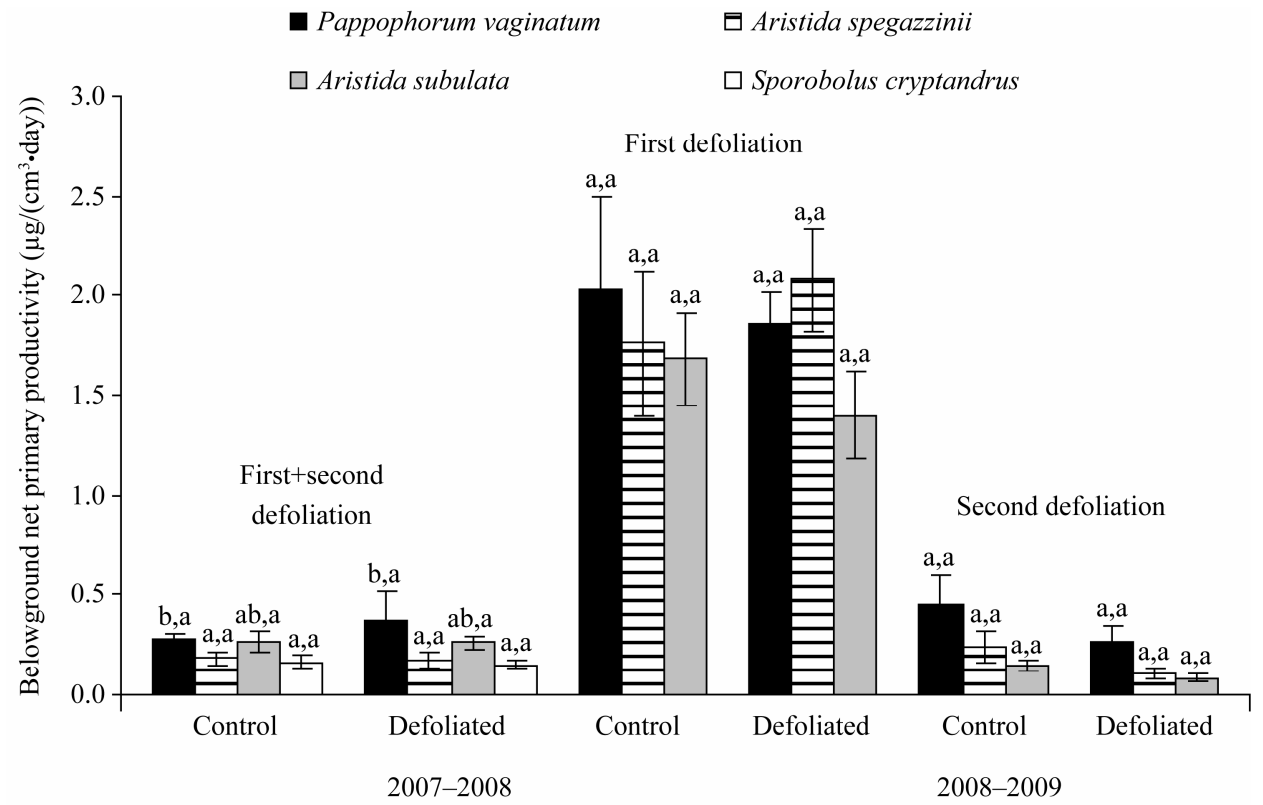

Fig. 2 Root net primary productivity of four warm-season grasses that were either exposed or not to defoliation during the growing seasons of August 2007 and September 2008. Each histogram is the mean \pm standard error of $n=6$. Different letters to the left of the comma indicate significant differences $(P<0.05)$ among genotypes, and those to the right of it indicate significant differences $(P<0.05)$ between defoliation treatments. 


\subsection{Root length density}

No differences were found between treatments $(P>0.05)$ during 2007-2008 (Table 3). At the same time, however, $P$. vaginatum showed higher $(P<0.05)$ root length densities than $A$. spegazzinii and $S$. cryptandrus. In December 2008, there were no significant differences $(P>0.05)$ neither among species nor between treatments (Table 3 ). Once again, there were no significant differences $(P>0.05)$ among species in April 2009; at this time, however, root length density of control was higher $(P<0.05)$ than that of defoliated plants.

\subsection{Root weight}

No differences $(P>0.05)$ were found neither among species nor between treatments during 2007-2008 and December 2008 (Table 4). However, higher $(P<0.05)$ root weights were found in $P$. vaginatum than in the other native species, and for control plants than defoliated plants in April 2009 (Table 4).

\subsection{Root length per unit root weight}

No differences $(P>0.05)$ were found between treatments during 2007-2008 and 2008-2009 (Table 5). During 2007-2008, all four native species showed a similar $(P>0.05)$ root length per unit root weight. However, A. subulata had a greater $(P<0.05)$ root length per unit root weight than the other three native species in April 2009 (Table 5).

Table 3 Root length density ( $\mathrm{cm} \mathrm{root} / \mathrm{cm}^{3}$ soil) on plants of four native species exposed to two defoliation treatments (Control, Defoliated) during 2007-2008 and 2008-2009

\begin{tabular}{ccccc}
\hline & & $25 \mathrm{Apr} 2008$ & $20 \operatorname{Dec} 2008$ & 4 Apr 2009 \\
\hline \multirow{2}{*}{ Pappophorum vaginatum } & Control & $0.20 \pm 0.02^{\mathrm{b}, \mathrm{a}}$ & $0.23 \pm 0.03^{\mathrm{a}, \mathrm{a}}$ & $0.180 .05^{\mathrm{a}, \mathrm{b}}$ \\
& Defoliated & $0.34 \pm 0.16^{\mathrm{b}, \mathrm{a}}$ & $0.23 \pm 0.02^{\mathrm{a}, \mathrm{a}}$ & $0.10 \pm 0.03^{\mathrm{a}, \mathrm{a}}$ \\
Aristida spegazzinii & Control & $0.17 \pm 0.03^{\mathrm{a}, \mathrm{a}}$ & $0.22 \pm 0.05^{\mathrm{a}, \mathrm{a}}$ & $0.08 \pm 0.02^{\mathrm{a}, \mathrm{b}}$ \\
& Defoliated & $0.14 \pm 0.02^{\mathrm{a}, \mathrm{a}}$ & $0.24 \pm 0.04^{\mathrm{a}, \mathrm{a}}$ & $0.04 \pm 0.01^{\mathrm{a}, \mathrm{a}}$ \\
\multirow{2}{*}{ Aristida subulata } & Control & $0.20 \pm 0.02^{\mathrm{ab}, \mathrm{a}}$ & $0.19 \pm 0.03^{\mathrm{a}, \mathrm{a}}$ & $0.07 \pm 0.01^{\mathrm{a}, \mathrm{b}}$ \\
& Defoliated & $0.14 \pm 0.03^{\mathrm{ab}, \mathrm{a}}$ & $0.20 \pm 0.02^{\mathrm{a}, \mathrm{a}}$ & $0.04 \pm 0.01^{\mathrm{a}, \mathrm{a}}$ \\
Sporobolus cryptandrus & Control & $0.12 \pm 0.02^{\mathrm{a}, \mathrm{a}}$ & n.d. & n.d. \\
\hline
\end{tabular}

Note: each value is the mean \pm standard error of $n=6$. Different letters in the same column indicate significant differences $(P<0.05)$ among species (first letter) or between treatments (second letter). n.d.: not determined

Table 4 Root weight (g/cylinder) on plants of four native species exposed to two defoliation treatments (Control, Defoliated) during 2007-2008 and 2008-2009

\begin{tabular}{|c|c|c|c|c|}
\hline & & 25 Apr 2008 & 20 Dec 2008 & 4 Apr 2009 \\
\hline \multirow{2}{*}{ Pappophorum vaginatum } & Control & $0.07 \pm 0.01^{\mathrm{a}, \mathrm{a}}$ & $0.13 \pm 0.03^{\mathrm{a}, \mathrm{a}}$ & $0.10 \pm 0.03^{\mathrm{b}, \mathrm{b}}$ \\
\hline & Defoliated & $0.11 \pm 0.05^{\mathrm{a}, \mathrm{a}}$ & $0.12 \pm 0.01^{\mathrm{a}, \mathrm{a}}$ & $0.06 \pm 0.02^{\mathrm{b}, \mathrm{a}}$ \\
\hline \multirow{2}{*}{ Aristida spegazzinii } & Control & $0.05 \pm 0.01^{\mathrm{a}, \mathrm{a}}$ & $0.11 \pm 0.02^{\mathrm{a}, \mathrm{a}}$ & $0.05 \pm 0.02^{\mathrm{a}, \mathrm{b}}$ \\
\hline & Defoliated & $0.05 \pm 0.01^{\mathrm{a}, \mathrm{a}}$ & $0.13 \pm 0.02^{\mathrm{a}, \mathrm{a}}$ & $0.02 \pm 0.00^{\mathrm{a}, \mathrm{a}}$ \\
\hline \multirow{2}{*}{ Aristida subulata } & Control & $0.08 \pm 0.02^{\mathrm{a}, \mathrm{a}}$ & $0.10 \pm 0.01^{\mathrm{a}, \mathrm{a}}$ & $0.03 \pm 0.01^{\mathrm{a}, \mathrm{b}}$ \\
\hline & Defoliated & $0.04 \pm 0.01^{\mathrm{a}, \mathrm{a}}$ & $0.09 \pm 0.01^{\mathrm{a}, \mathrm{a}}$ & $0.02 \pm 0.00^{\mathrm{a}, \mathrm{a}}$ \\
\hline \multirow{2}{*}{ Sporobolus cryptandrus } & Control & $0.05 \pm 0.01^{\mathrm{a}, \mathrm{a}}$ & n.d. & n.d. \\
\hline & Defoliated & $0.08 \pm 0.01^{\mathrm{a}, \mathrm{a}}$ & n.d. & n.d. \\
\hline
\end{tabular}

Note: each value is the mean \pm standard error of $n=6$. Different letters in the same column indicate significant differences $(P<0.05)$ among species (first letter) or between treatments (second letter). n.d.: not determined. 
Table 5 Root length per unit root dry weight $(\mathrm{m} / \mathrm{g})$ on plants of four native species exposed to two defoliation treatments (Control, Defoliated) during 2007-2008 and 2008-2009

\begin{tabular}{|c|c|c|c|c|}
\hline & & 25 Apr 2008 & $20 \mathrm{Dec} 2008$ & 4 Apr 2009 \\
\hline \multirow{2}{*}{$\begin{array}{l}\text { Pappophorum } \\
\text { vaginatum }\end{array}$} & Control & $54.57 \pm 2.33^{\mathrm{a}, \mathrm{a}}$ & $36.93 \pm 2.71^{\mathrm{a}, \mathrm{a}}$ & $36.80 \pm 2.88^{\mathrm{a}, \mathrm{a}}$ \\
\hline & Defoliated & $57.54 \pm 2.82^{\mathrm{a}, \mathrm{a}}$ & $38.52 \pm 1.79^{\mathrm{a}, \mathrm{a}}$ & $38.51 \pm 3.70^{\mathrm{a}, \mathrm{a}}$ \\
\hline \multirow{2}{*}{$\begin{array}{c}\text { Aristida } \\
\text { spegazzinii }\end{array}$} & Control & $64.72 \pm 11.16^{\mathrm{a}, \mathrm{a}}$ & $41.54 \pm 4.60^{\mathrm{a}, \mathrm{a}}$ & $39.93 \pm 4.26^{\mathrm{a}, \mathrm{a}}$ \\
\hline & Defoliated & $61.21 \pm 5.61^{\mathrm{a}, \mathrm{a}}$ & $40.85 \pm 3.41^{\mathrm{a}, \mathrm{a}}$ & $43.34 \pm 6.54^{\mathrm{a}, \mathrm{a}}$ \\
\hline \multirow{2}{*}{$\begin{array}{l}\text { Aristida } \\
\text { subulata }\end{array}$} & Control & $58.65 \pm 8.92^{\mathrm{a}, \mathrm{a}}$ & $40.75 \pm 2.30^{\mathrm{a}, \mathrm{a}}$ & $59.16 \pm 15.94^{\mathrm{b}, \mathrm{a}}$ \\
\hline & Defoliated & $70.25 \pm 7.87^{\mathrm{a}, \mathrm{a}}$ & $50.47 \pm 5.85^{\mathrm{a}, \mathrm{a}}$ & $53.89 \pm 7.24^{\mathrm{b}, \mathrm{a}}$ \\
\hline \multirow{2}{*}{$\begin{array}{l}\text { Sporobolus } \\
\text { cryptandrus }\end{array}$} & Control & $54.15 \pm 8.51^{\mathrm{a}, \mathrm{a}}$ & n.d. & n.d. \\
\hline & Defoliated & $58.66 \pm 6.70^{\mathrm{a}, \mathrm{a}}$ & n.d. & n.d. \\
\hline
\end{tabular}

Note: each value is the mean \pm standard error of $n=6$. Different letters in the same column indicate significant differences $(P<0.05)$ among species (first letter) or between treatments (second letter). n.d.: not determined.

\section{Discussion}

Root growth into the residues-free cylinders was quite different among the native species. Even though tiller density was lower in P. vaginatum than in the Aristida species, $P$. vaginatum showed greater root net primary productivity, and root length density than the other native species, but $A$. subulata, during the first study year. Pappophorum vaginatum also showed a greater root net primary productivity than A. subulata and $S$. cryptandrus, and a greater root weight than $A$. spegazzinii, A. subulata and S. cryptrandrus after two successive defoliations during the second year of the study. A greater root growth allows the occupation of a greater soil volume and exploration of nutrient-rich patches (Ivans et al., 2003). However, a greater root growth does not necessarily mean an immediate acquisition of soil resources (Eissenstat and Caldwell, 1989). An evaluation of simultaneous nutrient uptake rates would be necessary to evaluate this theory. Study results suggest that root proliferation (toward disturbed soil) would be a mechanism contributing to determine very likely a greater competitive ability in $P$. vaginatum than in the other native species in the study community.

Modifications in root growth in response to defoliation constitute an important mechanism for herbivory tolerance and maintenance of competitive ability for any species in the community (Briske and Richards, 1995). Rainfall was $65.5 \mathrm{~mm}$ and $97.5 \mathrm{~mm}$ during the whole study periods in 2007-2008 and 2008-2009, respectively. This may have contributed that root net primary productivity values appeared to be greater during the second than the first growing period in all study species. Other field studies have shown that grass root growth was enhanced under higher rainfall regimes at the same site (Fiala et al., 2012).

After two successive years of defoliation, and when plants were defoliated twice a year, both root length density and weight were lower on defoliated than on undefoliated controls in all study native species. Other field studies have also reported a decreased grass root growth as defoliation frequency increased (Gittins et al., 2010). However, a difference in root net primary productivity was not detected neither during the first nor the second growing season between defoliated and undefoliated plants of these species. Maintenance of root net primary productivity without reducing aboveground plant growth after defoliation during the first study year (Torres, 2011) very likely contribute to herbivory tolerance in the study species. The degree of root weight loss can also be affected by environmental factors (Silver and Miya, 2001).

The greater root length per unit root weight in $A$. subulata would give this species a greater uptake surface area and an advantage in the event of scarce precipitations $(<5 \mathrm{~mm}$; Ivans et al., 2003) that are common at the study site (Busso, 1997). For example, more than $60 \%$ of the precipitation events at the Chacra Experimental de Patagones were $<5 \mathrm{~mm}$ during 1983-2000 (Páez et al., 2005). Precipitations of this magnitude are capable of stimulating several physiological processes in grass species (Ivans et al., 2003). A rapid root growth early in the growing sea- 
son and an important root development in the superficial soil layers have been reported in other Aristida species (Evans and Tisdale, 1972). This would allow adaptation of these species to sites where soil moisture disappears early from superficial horizons during the growing season.

Our results indicated that root proliferation, in terms of root net primary productivity, and root both length and weight, can be higher in the more abundant, $\mathrm{C}_{4}$, warm-season $P$. vaginatum than in the other less abundant, $\mathrm{C}_{4}$, warm-season native species, and that these variables can be modified as a result of defoliation. Saint Pierre et al. (2002) and Saint Pierre and Busso (2006), working with $\mathrm{C}_{3}$, cool-season species, showed a greater root proliferation and root length density in the more competitive Nasella clarazii than in less competitive $N$. tenuis and A. ambigua. It is known that a greater root proliferation and root length density contribute to a greater competitive ability, but further research is necessary to determine if competitive ability is either greater or not in $P$. vaginatum than in the other native perennial grasses. Anyhow, the greater root proliferation in $P$. vaginatum than in the other native species, a parameter that contributes to competitive ability, could help to explain its greater abundance in rangelands of central, arid Argentina. Our results also suggest that root proliferation may be a good indicator of competitive ability not only in $\mathrm{C}_{3}$ but also $\mathrm{C}_{4}$ perennial tussock grasses in rangelands of northeastern, arid Patagonia.

\section{Conclusions}

Pappophorum vaginatum, the dominant warm-season perennial grass in rangelands of northeastern Argentina, showed an average root length density and weight per unit soil volume greater $(20 \%$ and $46 \%$, respectively) than the other native perennial grasses. These characteristics most likely contribute to explain its dominance among the warm-season perennial grasses available for livestock grazing, and persistence in rangelands of arid Patagonia. Despite its dominance and persistence, however, availabilities of $P$. vaginatum, and that of the other less preferred native warm-season perennial grasses, are not enough to cover forage demands of grazing livestock. Current research is evaluating the introduction of various warm-season perennial grasses (e.g., genotypes of Achnatherum hymenoides, Leymus cinereus, etc) at the study site to increase the supply of the current, and scarce, forage for grazing livestock from $P$. vaginatum, Aristida species, and S. cryptandrus.

\section{Acknowledgement}

We thank financial support from the National Council for Scientific and Technological Research of Argentina (CONICET; PIP Ner. 00211).

\section{References}

AOAC (Association of Official Agricultural Chemists). 1965. Official Methods of Analysis of the Association of Official Agricultural Chemists, $10^{\text {th }}$ ed. Washington DC: Association of Official Agricultural Chemists.

Briske D D, Richards J H. 1995. Plant responses to defoliation: a physiological, morphological and demographic evaluation. In: Bedunah D J, Sosebee R E. Wildland Plants: Physiological Ecology and Developmental Morphology, Denver: Society for Range Management, 635-710.

Busso C A. 1997. Towards an increased and sustainable production in semiarid rangelands of Central Argentina: two decades of research. Journal of Arid Environments, 36: 197-210.

Cabrera A L. 1976. Phytogeographical regions of Argentina. In: Ferreira Sobral E F. Argentinian Encyclopedia of Agriculture and Gargening. Buenos Aires: ACME.

Caldwell M M, Richards J H. 1986. Competing root systems: morphology and models of absorption. In: Givnish T J. On the Economy of Plant Form and Function. Cambridge: Cambridge University Press, 251-273.

Caldwell M M, Manwaring J H, Durham S L. 1991a. The microscale distribution of neighboring plant roots in fertile soil microsites. Functional Ecology, 5: 765-772.

Caldwell M M, Manwaring J H, Jackson R B, 1991b. Exploitation of phosphate from fertile soil microsites by three Great Basin perennial when in competition. Functional Ecology, 5: 757-764.

Casper B B, Jackson R B. 1997. Plant competition underground. Annual Review of Ecology and Systematics, 28: 545-570.

Crick J C, Grime J P. 1987. Morphological plasticity and mineral nutrient capture in two herbaceous species of contrasted ecology. New Phytologist, 107: 403-414.

Di Rienzo J A, Casanoves F, Balzarini M G, et al. 2009. InfoStat. INFOSTAT Group. Argentina: National University of Córdoba.

Distel R A, Bóo R M. 1996. Vegetation states and transitions in temperate semiarid rangelands of Argentina. In: West E N. Proceeding of $\mathrm{V}^{\text {th }}$ International Rangeland Congress. Rangelands in a Sustainable Biosphere Society for Range Management, Salt Lake City, 


\section{$117-118$.}

Dunn J P, Frommelt K. 1998. Effects of belowground herbivory by Diabrotica virgofera (Coleoptera) on biomass allocation and carbohydrate storage of mayze. Applied Soil Ecology, 7: 213-218.

Eissenstat D M, Caldwell M M. 1989. Invasive root growth into disturbed soil of two tussock grasses that differ in competitive effectiveness. Functional Ecology, 3: 345-353.

Evans G R, Tisdale E W. 1972. Ecological characteristics of Aristida longiseta and Agropyron spicatum in west-central Idaho. Ecology, 53: 37-142.

Fiala K, Tůma I, Holub P. 2012. Interannual variation in root production in grasslands affected by artificially modified amount of rainfall. The Scientific World Journal, doi: 10.1100/2012/805298.

Fitter A H. 1976. Effects of nutrient supply and competition from other species on root growth of Lolium perenne in soil. Plant and Soil, 45: 177-189.

Fowler N L. 1986. The role of competition in plant communities in arid and semiarid regions. Annual Review of Ecology and Systematics, 17: 89-110.

Giorgetti H D. 1995. Conference on cattle raising in shrublands. Chacra Experimental de Patagones, Viedma, Argentina. 56.

Giorgetti H D, Montenegro O A, Rodríguez G D, et al. 1997. The comparative influence of past management and rainfall on range herbaceous standing crop in east-central Argentina: 14 years of observations. Journal of Arid Environments, 36: 623-637.

Giorgetti H D, Montenegro O A, Rodríguez G D, et al. 1998. Effects of previous managements in the Phytogeographical Province of the Monte: plant density. In: $22^{\text {nd }}$ Argentinian Congress of Animal Production, Córdoba, Argentina, 101.

Giorgetti H D, Montenegro O A, Rodríguez G D, et al. 1999. Effects of previous managements in the Phytogeographical province of the Monte: percentage cover. In: $19^{\text {th }}$ Meeting of the Argentinian Association of Ecology. Tucumán, Argentina, 100.

Giorgetti H D, Montenegro O A, Rodríguez G D, et al. 2000a. Frequency of herbaceous and woody species in rangelands of Central Argentina recovering from disturbances. In: $23^{\text {rd }}$ Argentinian Congress of Animal Production, Corrientes, Argentina, 138-139.

Giorgetti H D, Manuel Z, Montenegro O A, et al. 2000b. Phenology of some herbaceous and woody species in central, semiarid Argentina. Phyton, International Journal of Experimental Botany, 69: 91-108.

Giorgetti H D, Busso C A, Montenegro O A, et al. 2006. Cattle raising in central, semiarid Argentina. Rangelands, 28: 32-36.

Gittins C, Busso C A, Becker G, et al. 2010. Defoliation frequency affects morphophysiological traits in the bunchgrass Poa ligularis. Phyton, International Journal of Experimental Botany, 79: 55-69.

Hodgkinson K C, Ludlow M M, Mott J J, et al. 1989. Comparative responses of the savanna grasses Cenchrus ciliaris and Themeda triandra to defoliation. Oecologia, 79: 45-52.

Ivans C Y, Leffler A J, Spaulding U, et al. 2003. Root responses and nitrogen acquisition by Artemisia tridentata and Agropyron deser- torum following small summer rainfall events. Oecologia, 134: 317-324.

Jackson R B, Caldwell M M. 1993. The scale of nutrient heterogeneity around individual plants and its quantification with geostatistics. Ecology, 74: 612-614.

Kaspar T C, Ewing R P. 1997. ROOTEDGE: software for measuring root length from desktop scanner images. Agronomy Journal, 89: 932-940.

Kilcher M R, Looman J. 1983. Comparative performance of some native and introduced grasses in southern Saskatchewan, Canada. Journal of Range Management, 36: 654-657.

Páez A, Busso C A, Montenegro O A, et al. 2005. Seed weight variation and its effects on germination in Stipa species. Phyton, International Journal of Experimental Botany, 1-14.

Quinn J A, Ward R T. 1969. Ecological differentiation in sand dropseed (Sporobolus cryptandrus). Ecological Monographs, 39: 61-78.

Saint Pierre C, Busso C A. 2006. Competitive ability and defoliation tolerance in Stipa clarazii, Stipa tenuis and S. ambigua. Phyton, International Journal of Experimental Botany, 75: 21-30.

Saint Pierre C, Busso C A, Montenegro O A, et al. 2002. Root proliferation in perennial grasses of low and high palatability. Plant Ecology, 165: 161-169.

Schacht W H, Smart A J, Anderson B E, et al. 1998. Growth responses of warm-season tallgrasses to dormant-season management. Journal of Range Management, 51: 442-446.

Shinoda M, Nachinshonhor G U, Nemoto M. 2010. Impact of drought on vegetation dynamics of the Mongolian steppe: a field experiment. Journal of Arid Environments, 74: 63-69.

Silver W L, Miya R K. 2001. Global patterns in root decomposition: comparisons of climate and litter quality effects. Oecologia, 129: 407-419.

Sokal R R, Rohlf F J. 1987. Introduction to Biostatistics. $2^{\text {nd }}$ ed. New York: Freeman.

St John T V, Coleman D C, Reid C P P. 1983. Growth and spatial distribution of nutrient-absorbing organs: selective exploitation of soil heterogeneity. Plant and Soil, 71: 487-493.

Svejcar T, Angell R, Bradford J A, et al. 2008. Carbon fluxes on North American rangelands. Rangeland Ecology and Management 61: 465-474.

Torres Y A. 2011. Morphophysiological characteristics and forage production in native, introduced and naturalized warm-season perennial grasses of the center of Argentina. Ph.D. Thesis, Bahía Blanca: Universidad Nacional del Sur.

Valentine J F. 1990. Grazing Management. San Diego: Academic Press, 533.

Wilks S S. 1932. Certain generalizations in the analysis of the variance. Biometrika, 24: 471-494.

Williams T E, Baker H K. 1957. Studies on the root development of herbage plants. I. Techniques of herbage root investigations. Journal of the British Grassland Society, 12: 49-55. 